\title{
Temple Vision as a Catalyst to Theological Convergence: Ecumenical Renewal in a Post-Ecumenical Era
}

\author{
Michelle G. Wiener (Author) \\ Religion Instructor, Rowan-Cabarrus Community College \\ E-mail: michelle.lyerlywiene@rccc.edu
}

I would like to thank Profs. Fr. Laurent Cleenewerck and Fr. Cajetan Ebuziem for their constructive feedback on an earlier draft of this article.

\begin{abstract}
The modern Ecumenical Movement actively seeks to establish visible unity among all Christendom. How this is to eventually take shape remains a mystery. Historically, there are four methods by which this process is understood: (1) Faith and Order, (2) Life and Work, (3) Common missionary efforts, and (4) A renewed commitment to theological education. Nevertheless, the search for visible unity remains problematic, when taking into account the further divisions that exist in the sacramental life of the Church, as the Lima 1982 Baptism, Eucharist and Ministry (BEM) document examines. The reality remains that the Church is nowhere closer to achieving the visible unity for which Jesus prayed in John 17:21. But what if we are not looking in the right place? What is the answer has been reiterated throughout the Scriptures all along - hidden in plain sight? The Temple, with its cube-shaped Holy of Holies, can provide a catalyst through which, not only visible unity, but a wider theological convergence, is achieved. As this essay will argue, Temple vision can become a catalyst to achieving the mystical unity for which Jesus prayed, as consistent with Christ's ecumenical imperative. In our increasingly technological world that is looking for mystical connections of a deeper nature, this may very well be what the world needs today.
\end{abstract}

Keywords: Temple, Visible Unity, Ecumenical, Theological Convergence

DOI: $10.7176 / \mathrm{JPCR} / 48-04$

Publication date:March $31^{\text {st }} 2020$

\section{Ecumenical Convergence in Crisis}

The modern Ecumenical Movement is characterized by a search for visible unity. However, the difficulty in defining this term sparks much debate within ecumenical circles, considering the manifold "diversities which are rooted in theological traditions." Historically, this search for visible unity has been known to take shape in one of four ways: (1) Faith and Order, or a common theology, (2) Life and Work, or a common commitment to social justice, (3) Collective missiological/missionary efforts, and (4) A renewed commitment to theological education. Additionally, as the 1982 Faith and Order Commission Lima document affirms, each denomination experiences further division in their practices related to Baptism, Eucharist and Ministry (BEM) with much of the debate surrounding the issue of proper authority to administer within the "constitutionally or canonically ordered" sacramental life of individual denominations. What becomes lost in this debate pertaining to visible unity is a lack of focus on the visible aspects of being unified. Further division results from the very act of debate itself. There seems to be no clear pathway for fully realizing Church Unity in accordance with Christ's ecumenical imperative outlined in John 17:21, "so that the world may believe." The Church has found itself in a postecumenical age; thus, it "requires the renewal of ecumenical vision." 3 The reality is the world stands in disbelief when it looks at what has become of the Christian Church, with so many divisions and theological disagreements. Is there a key to visible unity? Or has the focus shifted in another direction - that of a wider mystical convergence? Temple Vision can provide a catalyst through which, not only visible unity, but a wider theological convergence, is achieved, as consistent with the deeper mystical unity for which Jesus prayed, as outlined in John 17:21.

\subsection{The Search for Mystical Unity}

The newly emerging academic field of Temple Theology offers insight into the true nature of Christ's ministry while on earth, which finds continuity in the life of the Body of Christ today in anticipation of the final eschaton, with the cosmic Temple - the New Jerusalem - descending from heaven in the form of a cube, as recorded in Revelation 21. In fact, as will be argued, mystical unity is found within the image of the cube itself as it stands as a testament to the unified nature of the Divine Reality in accordance with Jesus' prayer for unity in which he prayed for us to be joined with him as he is joined with his Father. This mystical unity culminates in the cubeshaped Holy of Holies, or inner sanctum, as it was originally housed in the inner sanctum of King Solomon's Temple. Referencing Isaiah 66:1, New Testament scholar Gregory K. Beale explains, "the holy of holies 
represented the invisible heavenly temple and throne of God...and it was the actual place where the heavenly dimensions extended down to earth." 4 Thus, it was the dwelling place of the Divine Council and the place where divine planning took place. In this respect, the cube-shaped Holy of Holies becomes a visible sign of the mystical unity for which Jesus Christ prayed as he was nostalgically looking back to a Temple long ago destroyed by the Babylonians in 587BCE. Seeing the corruption in the refurbished Temple of King Herod, Jesus was not only lamenting an earlier time in Israel's history, but was looking forward to the day when the cosmic heavenly Temple would be revealed to a creation longing for renewal, both on a cosmic level, and in real time.

\subsubsection{Alternative Models}

In a world that is looking for alternative forms of spirituality transcending a strictly 'biblical' model, this search for a visible, mystical unity becomes all the more necessary, especially within our increasing technological age. Today, people are searching for a connection to the spirit realm, with a need to see unity in nature and the search for life after death. This is evidenced by the recent obsession in our culture with Near Death Experiences (NDE), reincarnation, meditation and God-realization, Gaia Consciousness, various methods of divination, and even goddess spirituality. What was once called 'New Age' spirituality has resurfaced and recycled itself for a new era in the form of neo-Gnosticism. While New Age/neo-Gnosticism appears on a surface level to be antithetical to the Bible, it really is not when considered in light of all the Temple has to offer. Neo-Gnosticism delves into the mystery in such a way that biblical Christianity would never dare. Nevertheless, such powerful spiritual connections exist historically in the Temple construct, which is both biblically-based and deeply mystical in approach. The spiritual and practical implications are rather astounding when considered in light of the cubeshaped Holy of Holies, which becomes a catalyst for the convergence of all things; moreover, echoing back to "the Unity of Day One" of creation in its original state in the presence of the unified Heavenly Hosts. It is precisely the Heavenly Host that represents the mystical unity of which Jesus speaks.

\subsubsection{Returning to the Source}

In King Solomon's original Temple, the Heavenly Hosts existed beyond the veil. Temple theologian Margaret Barker argues that the reason for this is the members of the angelic hosts - or the Divine Council - are all derived from the same source, as "the unity within the holy of holies meant that all the angels were derived from the One." This is evidenced by the fact that the Veil, which was woven from blue, scarlet and purple, included engravings of the Heavenly Host and served as a boundary between this world and the next. The area behind the veil represents a singularity of purpose in the Divine Presence. The High Priest who enters through the veil is then transformed in the Presence of the Divine Council and becomes an exalted being endowed with power from on high for the purpose of returning, or being "sent out into the great hall of the temple," "both to bless and proclaim restoration and renewal to the outside world, inclusive of both the visible creation and broken humanity. Within the Temple is found the possibility of God-realization and eventual apotheosis, or exaltation through which humanity can become 'like God,' much like New Age/neo-Gnostic spirituality seeks to do. This is a clear reversal of the curse reiterated by the serpent in Genesis 3:5 through which humanity seeks to attain godlike status through foolish pride. In his prayer for unity, the Great High Priest is calling us to forsake the cares of this world and join him in affirmation of that essential unity through the transformative power of the Atonement. Apotheosis remains a collective, as well as an individual effort.

\section{A Lost Relic}

So much of what was housed in the original Temple of King Solomon was lost throughout time, due not only to King Josiah's reforms, but later through a renewed emphasis upon the Mosaic Law in Second Temple Judaism, accompanied by lengthy rabbinic interpretations which would later inform the Talmudic traditions. Jesus and his followers were very much aware of this fact, as can be seen in Jesus' rather harsh dialogue with the Pharisees. Barker points out that "the Christians were the heirs of those who rejected the second temple and its tradition, and longed for the restoration of the true temple." "But this is not all that was lamented by Jesus and his followers. The reforms of King Josiah, in attempts to return to the strictness of the Mosaic Law, reveal an inner physical cleansing of the Temple itself, in terms of the items housed in it. II Kings 23 records that the items removed from the original Temple included the vessels used for idolatrous purposes, but among those items are included the vessels dedicated to the Hosts of Heaven and other heavenly bodies, all of which had been grinded to dust, burned to ashes, and dumped in the brook of the Kidron Valley. The sacred groves, or high places devoted to Asherah worship had also been destroyed, along with the items devoted to Asherah housed in the Temple, which most likely included the seven-branched menorah, as a stylized tree. As Barker explains, "the account of Josiah's purge must include within it somewhere the removal of the ark, the menorah, the oil, manna and high priestly staff, and the cherubim, presumably of the throne." 9 The tree imagery here implies a lost sacred feminine presence often identified in the sacred scriptures as Wisdom personified (see Proverbs 8), and represented as the Tree of Life, as well as the mysterious Bread of the Presence (see Jeremiah 7:18). Alongside these destroyed items are the sacred vessels traditionally associated with Baal worship. 


\subsection{Lost to Time}

Herein resides the central problem. The real cause for idolatry lied not in the sacred groves "where the women wove hangings" (II Kings 23: 7) or even with the sacred vessels housed in the Temple in honor of this lost sacred feminine presence, but in the indiscriminant coupling of Baal worship with the veneration of this lost feminine presence. The entire prophetic book of Hosea serves as a metaphor for this, wherein the children of Israel have 'prostituted' themselves by giving into the lewd fertility rites that grew to characterize Baal worship throughout the Fertile Crescent. Additionally, "in Hosea we see stark condemnation of the fertility rites associated with holy trees" 10 resulting from indiscriminant religious syncretism. Hosea 2:8 declares, "She did not know that it was I who gave her the corn, and wine, and oil, and multiplied her silver and gold, which they prepared for Baal" (KJV). Baal worship was the central problem. But Baal worship crept in slowly as the Hebrews began to settle in the Promised Land of Canaan following the conquests of Joshua; eventually it crept into Temple worship. The question remains as to how this happened, which hints at a much earlier system of religious practices predating the conquest, and Abraham even.

\subsubsection{Maintaining Historical Perspective}

It must be kept in mind that Abraham originated from Ur of Chaldea, located in ancient Babylon. Having been raised in a polytheistic context, Abraham understood the call of this unknown deity from within that cosmological framework. There is even evidence to suggest that Abraham's wife Sarah may have held priestesshood status, as the name Sarah suggests a phonetic connection with the goddess Asherah. The tale-tale sign of this ancient goddess connection is found in the story in which the three mysterious visitors appear to Abraham and Sarah at Mamre and announce that she will conceive a son in her old age. With Mamre being Sarah's ancestral home, Mamre remains surrounded by a sacred grove of oak trees and the terebinth, "a small deciduous tree native to the Mediterranean region." 11 Later the sacred groves would become a symbol for Asherah, as would the menorah housed in the Temple representing the Tree of Life. Early on, it would seem that the God Most High, El Elyon, had a wife, also known as the Queen of Heaven.

2.1.2 Emergent Competition

As evidence would suggest, the ancient Hebrews turned to Baal worship as they entered Canaan. Baal, aptly described as "the virile dim-bulb," 12 being the god of the storms, and therefore the bringer of rain, would become the natural go-to deity whenever there was a drought in the land. Thus, there remained stiff competition between Baal and Yahweh, even when it came to attracting the attention of the goddesses. It is important to note that historically, Baal was represented as a bull, but the bull was also a prominent symbol for Yahweh, or the Angel of the Lord. Yahweh served as the chief representative of the Heavenly Host to whom Israel was partitioned following the Tower of Babel incident, as described in Deuteronomy 32:8, when "Yahweh received Israel for his portion when El Elyon divided the nations among the sons of God."13 It should be noted that El Elyon means 'God Most High,' which suggests lesser divinities, or members of the angelic realm working under the direction of the highest divinity, forming a Hebrew pantheon, of sorts. It would only be under the Mosaic Law that a distinctive monotheistic stance would be carved out. Nevertheless, these quasi-polytheistic connections stood as remnants of a much older belief system.

\section{Quasi-Polytheistic Context}

This even suggests a possible father-son relationship between El Elyon (El) ${ }^{14}$ and Yahweh, with the implication being El Elyon could not father a son alone without the help of a consort. As Barker points out, "There are those called sons of El Elyon, sons of El or Elohim, all clearly heavenly beings, and there are those called sons of Yahweh or the Holy One who are human." 15 It would appear from this perspective that the Canaanites were partitioned out to Baal, a 'lesser' elohim (divinity), while Israel was partitioned out to Yahweh. Thus, the children of Israel would become the children of Yahweh, specially chosen as "a kingdom of priests and an holy nation" (Exodus 19:6) This father-son distinction is crucial when considered in light of Jesus' prayer for unity, assuming as did the early Christians that Jesus was indeed the Son of God. Distinguished Hebrew scholar Raphael Patai suggests that what happened over time as the Hebrews settled in Canaan in the thirteenth century $\mathrm{BCE}$, is a conflation between Yahweh and Baal, as "other Israelites, probably less sophisticated religiously, considered Baal a competitor of Yahweh and switched to his worship; still others served the two gods alternatingly as dictated by circumstances." 16 This would make sense in an agricultural society, in which the gods were believed to have intricate connections to the hidden powers of nature; perhaps certain deities were viewed as more powerful than others - thus the temptation to follow after other gods.

\subsection{Deity Conflation}

This conflation of deities was common throughout the ancient world, as the Baal Cycle represented a larger tradition of "storm god-slays-dragon myth" 17 motif spanning throughout through the entire Levant, all the way to ancient Persia, and moreover reflective of an agricultural mindset. Old Testament scholar Robert D. Miller further notes how in the Ancient Near East, "storm gods become mutually interchangeable;" 18 given they have 
different names but similar functions. Hebrew Bible and Ancient Near Eastern culture scholar Ryan Thomas follows this same line of thought, "We have many examples from the ancient Near East where a deity is known by multiple epithets (e.g., El = Shaddai, Elyon, Baal, etc), and the use of a common noun as though it were a proper name is certainly not exceptional." ${ }^{19}$ By the First Temple period, the veneration of Baal in place of Yahweh was in full swing. In efforts to destroy Baal worship, King Josiah did away with everything that had become corrupted by that foreign religious system, until all that was left was the strict Mosaic Law. And his purge brought with it dire consequences.

\subsubsection{The Hosts of Heaven}

Driven out alongside the vessels associated with the Baal and Asherah worship were the tools dedicated to discerning the times, astrologically speaking: "to the sun, and to the moon, and to the planets, and to all the hosts of heaven" (II Kings 23: 5). In the ancient world, the heavenly bodies not only dictated the course of human events; they were believed to be representatives among the Heavenly Hosts - gods even. Ancient temples served as observatories of heavenly patterns, with the fixed constellations telling stories. Nevertheless, even among the Hebrews, the fixed constellations "were not arbitrary arrangements but were living beings that impacted on each other and on the earth." ${ }^{20}$ While Babylonian, Persian, among other astrological systems, dictated the course of human events, and even foretold the futures of individual humans, the Mazzaroth of the Hebrews did nothing of the sort. It simply told the story of redemption. However, one can see how it may have become corrupted through its popular association with Canaanite mythology and subsequent religious syncretism.

\subsubsection{Astrological Connections}

With astrology having its roots in ancient Babylon, Abraham would have been familiar with the popular associations. The biblical story from Genesis to Revelation is filled with astrological references and connections, from the twelve tribes to Israel, to the lion (Leo) and lamb (Aries) imagery found in Revelation, along with the mysterious Revelation 12:1-2 sign foreshowed in Isaiah 7:14, popularly associated with the constellation Virgo. These signs in the heavens echo back to an ancient cosmology in which the heavens revealed a vast plan of redemption to the ancient Hebrews. The reforms of Josiah reveal a switch in calendars, from a solar to a lunisolar system, given "the writings of the exile and post-exilic period assume a spring new year, but the most ancient calendar had begun in the autumn." ${ }^{21}$ Even today, Rosh Hashanah, the Jewish new year, begins in the fall months, with the Day of Atonement, or Yom Kippur following. It is interesting how when the Persian Magi appear to the Holy Family, they do so by following the signs in the heavens. This is not coincidental, as Jesus' true mission echoes certain nostalgia for the First Temple Period. The continuation of these themes throughout the Book of Revelation reflects this sentiment, with the various heavenly signs.

\section{Enoch and the Watchers}

However, there remains much more to Jesus' true mission objective than meets the eye. This includes the eventual abolishment, not only of evil in its various manifestations, but of its true origins, of which very little is said in the Hebrew Bible. Genesis 6:1-4 offers a clue, but then it is just assumed from there the reader knows the contextualized story, of which later New Testament writers only offer glimpses. Genesis 6:2 mentions the beneelohim, or 'sons of god' - also known as the Watchers - who according to chapter six of the Book of Enoch, swear a sacrilegious oath on the summit of Mount Hermon to corrupt humanity both through illicit relations with human women and by introducing them to the dark arts, including warfare, jewelry, cosmetics, witchcraft, and astrology, as recorded in the next chapter. From there, the Nephilim, or a race of hybrid giants, are born, and they continue to wreak havoc on humanity until the time of the Flood. Following the Flood, their spirits remain behind to further torment humanity. These are the demons of the New Testament, chief among them Baal-zebub, or the Lord of the Underworld.

\subsection{Heiser's Thesis}

Michael S. Heiser sheds additional light on the true focal point of Jesus' earthly ministry, as pertaining to the writings of Enoch. While most Christians assume Christ's atoning sacrifice on the cross is the keystone of the Gospel message, Heiser argues that Jesus' true agenda was to reverse the curse of the Watchers, who had descended upon Mount Hermon "in the days of Jared" (Enoch 6:6) and swore a collective oath to corrupt humanity. This is coupled with the tacit understanding that "the Fall of Adam is not the exclusive touchpoint for the depravity of humankind." 22 Throughout Reversing Hermon, Heiser argues that the story of Peter's confession recorded in Matthew 16:13-20 took place at the base of Mount Hermon -- located in the northern hill territory of Bashan along the Sea of Galilee - it was there Jesus made his infamous 'upon this rock' declaration. This northern area was not only frightening due to its remote, and therefore unpredictable nature, but it was literally "considered the gates of hell," 23 given it was both dedicated to the Greek god Pan and included an altar dedicated to Baal. It was popularly believed that the Watchers were chained beneath Mount Hermon to be released at the end of time. Coincidentally, it is important to note that the summit of Mount Hermon rests on the thirty-third parallel, an area commonly known for its heightened spiritual activity in esoteric circles, even today. 
Heiser, a former evangelical, believes that Mount Hermon is the rock upon which Christ declares the inauguration of the Kingdom of Heaven, and not Peter. If Heiser's theory is correct, this completely reverses the claim to apostolic primacy; moreover, leveling the ministerial playing field, so to speak. Heiser does acknowledge the division among Catholics and Protestants surrounding the correct interpretation of verse eighteen, adding "the former argue that Peter is the rock upon which the church is established and thus the passage makes Peter the leader of the original church," ${ }^{24}$ while Protestants argue the true foundations of the church rest on Peter's confession of Christ. To this Heiser declares, "Both of these traditional understandings are incorrect" 25 because Christ is simply making a reference to the place where he and the disciples are standing. While this may appear on the surface to be a bold statement on Heiser's part, the implications of such a statement cause reason to stare when considering the connection of this place with Baal and the Enochian Watchers. In his reply to Peter's confession, Jesus is declaring that victory over Baal - his chief rival - and the assailant powers of the underworld is imminent. Standing there at the place where the damage was done, Jesus declares a reversal of the curse placed on humanity by the Watchers and their wicked secret combinations. Additionally, Richard C. Steiner of Yeshiva University notes that Baalbek, the valley region below Mount Hermon, contained an epithet inscription to El in Phoenician, dating back to the time of the prophets Amos and Hosea. ${ }^{26}$ If this is the case, Jesus was simply reclaiming his rightful territory.

4.1.1 The Primacy Question

If Heiser's thesis is taken seriously, then this verse has little, if anything, to do with ministerial or apostolic authority. This puts a whole new spin on the ecumenical dilemma expressed in the Lima Baptism, Eucharist and Ministry (BEM) document drafted in the Faith and Order Conference of 1982, in which it was discovered that the issue of ministry stands in the way of Church unity, due to the question of proper authorization to administer in the Sacramental Life of the Church - namely, the remaining sacraments of Baptism and Eucharist. While affirming the historical and traditional legitimacy of the threefold ministry of Bishops, Presbyters, and Deacons, the 1982 Lima document simultaneously declares, "there is no single New Testament pattern,"27 or model, for the ministry. Anglican Archdeacon Ormonde Plater concurs, "The threefold ministry has been generally adopted and exists in the large majority of churches today" 28 Bishop Emeritus Peter Cullinane affirms that while Catholic tradition operates in good faith that its structure is in keeping with Christ's original ministerial model; he simultaneously admits, "its structure and concrete forms were determined by the church, during the apostolic period and continuing until late in the second century." ${ }^{29}$ With this kept in mind, if the 'rock' upon which Christ builds his church is purely locational in origin, then the real focus should be placed 'upon that rock' in a joint effort to, in the words of the Theosophical Great Invocation, "seal the door where evil dwells," 30 which is, in this case, Mount Hermon. Even those within neo-Gnostic and other esoteric circles recognize the importance of this. 4.1.2 Singular Trajectory

As Heiser points out, shutting the door to evil is not a matter of battling invisible demons in the sky; rather it is a matter of confronting evil in all its various manifestations, just as Jesus announces defeat of Baal and his legions on Mount Hermon. Heiser explains that gates are, by definition "defensive structures, not offensive weapons." 31 Modern day disciples of Jesus Christ have the sacred obligation to declare with one unified voice victory over the powers of hell and darkness. As Heiser further explains, "Hell has no claim on those who align themselves with Jesus. He will reverse the curse of death and His own will rise on account of Him." 32 Denominational disputes aside, this is why visible unity is essential. As Jesus' prayer for unity in John 17:21 attests, the Gospel hinges on a singularity of purpose in efforts to claim the keys to the kingdom, just as the Heavenly Hosts stood unified in the cube-shaped Holy of Holies. Clearly Jesus was seeing the world through First Temple eyes.

\section{Developing Temple Vision}

While certain vestiges of the Temple are contained in liturgy, church architecture, and even throughout the pages of biblical history, the Church has lost its essential connection with Temple cosmology and language. Nevertheless, the Temple remains the catalyst to understanding the original intent of why Jesus came to earth and what he hoped to accomplish while here; therefore, it $i s$ the key to the Kingdom. Housed within the Temple is veiled symbolism that reveals God's vast plan for human redemption and the promised renewal of creation, such as representations of mountains, trees, vegetation, animals, and even the elements such as fire and water. For instance, the Altar of the Sacrifice housed in the Outer Court resembled a mountain, or the 'high places,' as they were called throughout the Old Testament, while the golden laver supported by twelve bulls and ceremonial water basins surrounding the Courtyard represented the bodies of water and the contained, yet ever-churning chaotic sea. The fully-functioning Levitical priesthood, administering alongside the High Priest, represent the human element operating in a spirit of unity and fully aligned with divine purpose.

\subsection{Shifting Emphasis}

The legitimate concern here is that the Gospel, especially in the Western world, has become reduced to a message of 'the cross,' - essentially a message of death -- when in reality, there should be a renewed emphasis on 
the Tree of Life. The Tree of Life was housed in the First Temple in the form of a towering seven-branched lampstand; moreover, it stood as a beacon of hope to all who basked in its warm, inviting glow. Lost to time, although symbolically present in Judaism in the form of the menorah, its restoration is promised in the Book of Revelation. In the Mormon tradition, the Tree of Life is a familiar symbol, with its fruit being described as "desirable above all other fruit" (I Nephi 8:12); yet it is no longer accessible. Yet, in the book of Revelation 22:2, its leaves are provided freely "for the healing of the nations." There is a profound sense of loss and return expressed here, as sinful humanity was shut out from partaking of the fruit of the Tree of Life in the Garden of Eden, which functioned as the very first earthly Temple wherein which humanity dwelt in perfect unity with Godhead. Beale explains that Adam, representing collective humanity, was charged with the priestly duty of cultivating and caring for the Garden by "maintaining its orderliness in contrast to the disordered space outside." 33 Adam was also expected to keep out all things that sought to corrupt this sense of wholeness and essential unity. Beale explains, "The picture, therefore, is that of a 'warden' managing a sacred ward." 34 Once this essential trust was breached by allowing evil to enter into the holy inner sanctum, humanity was longer counted worthy of the priestly task. Something had to be done to correct this.

\subsubsection{Return to Eden}

The hope for the eventual restoration of Eden would become symbolized in the Temple construct in its various forms throughout Israel's history. It began on the mountaintops and in the sacred groves in Israel's pre-history, seen in both the mountaintop sacrifices offered by the Hebrew patriarchs, to the sacred groves among the oaks and terebinths of Mamre, matriarch Sarah's ancestral home. Within both contexts, nature becomes the setting in which the divine manifests itself to humanity in its various theophonic forms; whether by way of three mysterious visitors, or by passing through the sacrifice in the act of affirming the sacred covenant with Abraham and his progeny, as recorded in Genesis 15:17. Beale states, "The result of Abraham, Isaac and Jacob building altars at Shechem, between Bethel and Ai, at Hebron, and near Mount Moriah was that the terrain of Israel's future land was dotted with shrines." 35 The act of sacrificing atop the high mountain is deeply symbolic, when taken into consideration the stark contrast between sacred covenants made between the patriarchs and God and the wicked covenant sworn by the Watchers upon Mount Hermon. Already, an act of reversal is set in place.

Later, the Temple vision would be expanded through the traveling Tabernacle in the Wilderness, which served as a precursor to the Temple. Beale notes a parallel between the mobile nature of the Tabernacle structure and the way the biblical patriarchs built their altars wherever they moved. The impermanent nature of these sanctuaries "symbolically represented the notion that their progeny were to spread out to subdue the earth from a divine sanctuary in fulfillment of the commission in Genesis 1:26-28."36 After King Solomon's Temple was built, it represented, in its three-tiered structure moving out from the Holy of Holies - the central core of the structure - this divine mandate to spread out into less holier spheres, just as the High Priest left the Holy of Holies to bless the children of Israel. The command in Isaiah 54:2 to "enlarge the place of thy tent" is Tabernacle language, and it rings true, not only to the Temple mission, but to Jesus' Great Commission in which he tells his disciples to "go ye therefore, and teach all nations, baptizing them in the name of the Father, and of the Son, and of the Holy Ghost" (Matthew 28: 19 KJV). Once again, Jesus is viewing the world through First Temple eyes.

\subsubsection{Enlarge the Borders}

The central purpose of expanding the Temple vision is to transform the earth itself back into the Garden of Eden, as "the borders of Eden and all subsequent temples were to be expanded until they circumscribed the globe with God's all-pervasive presence." 37 In other words, the Shekinah glory, which filled the Holy of Holies in the form of a cloud, would eventually find its way outside the Holy of Holies and cover the entire earth, just as the cloud followed the children of Israel as they sojourned through the desert; nevertheless, both King Solomon and his father David were aware of the true origins of this thick cloud, which "surrounded the LORD and his throne." 38 Among the Wisdom literature, Ben Sira 24:4 speaks on behalf of the feminine Shekinah presence also known as Wisdom, "I dwelt in the highest heavens, and my throne was in a pillar of cloud" (NRSV w/ Apocrypha). The Spirit of Wisdom, also known as Chokmah in Judaism, served as a guide and guardian for her people as they moved from one place to another throughout history.

\section{Return and Rebuild}

As time would go on, the Hebrews would return from Babylon and rebuild under the decree of King Cyrus of Persia; however, the conditions were never ideal. The Qumran Essene community is a testament to the corruption found within Second Temple worship, both in terms of the priesthood leadership and their surmounting rules and regulations. Second Temple loyalty to Roman rule would only add to the conflict and confusion. It was within this context that Jesus was born. His disdain for King Herod's Temple is evident in his constant arguing with the Pharisees and Saducees over various interpretations of the Mosaic Law. His use of parables alone served as evidence of his love for the Wisdom teachings, as well as his emphasis upon the Spirit of the Law (derived from the Hebrew Prophetic tradition) over a literal interpretation. From this perspective, it would appear that Jesus' approach to the Scriptures did indeed echo back to an earlier time when Temple 
mysticism prevailed over the letter of the Law. Domeris points out that Jesus' episode with the moneychangers in the Temple reveals how the economic root of the problem detracted from the deeply spiritual nature of Temple symbolism. Considering the fact that "both Roman and Priestly taxes were stored in the temple," 39 corruption within the Temple remains evident.

\subsection{Consequences of Idolatry}

Although Josiah's reforms sought to correct the idolatrous practices of the time; in actuality, what it did was to stamp out any freedom of interpretation or religious expression. Jesus fully understood the implications of this. All awe-inspiring practices of a deeply mystical or spiritual nature were subsequently banished from the Temple grounds - including the Hosts of Heaven and this mysterious Sacred Feminine presence. Thereafter, Israel would lose its grounding and the Temple would be destroyed as the Israelites were carried off in captivity to Babylon. While it is true that idolatry was stamped out of Temple worship, doing so carried with it a huge price.

A renewed definition of the Temple would resurface in attempts to reinterpret its role in light of both Jesus' death for Christians, and the subsequent destruction of King Herod's Temple in 70CE for both Jews and Christians. For Jews, the Synagogue would replace the Temple as a center for instruction and learning. For Christians, the concept of the unified Church as the Body of Christ would come to replace the Temple construct, as the Gospel was embraced in the regions surrounding Jerusalem, and even beyond, the search for visible unity became problematic, especially with regional, cultural, and later denominational misunderstandings. The Ecumenical Movement has sought over the years to recover that loss, but the divisions remain. Visible unity remains a distant goal yet to be fully realized, just as the Kingdom of God is in a constant flux state of 'already' and 'not yet.' When professing Christians cannot even share the common cup, break bread together, or acknowledge a common baptism as joint members of the same Body, something is clearly amiss. Theological discourse also provides a barrier to visible unity because no two sides can agree. It would seem in light of this failure to achieve visible unity, the push for a deeper mystical convergence becomes all the more necessary.

6.1.1 Towards Creative Coalescence

Looking to the Temple could provide new avenues for theological discourse among the various denominations by presenting a clearer picture of the role and function of the Body of Christ. In other words, the Church needs to develop Temple vision. Ephesians 2:20 declares Jesus Christ as the "chief cornerstone" of the Church. Through the unifying power of the Holy Spirit, "the Church is called to proclaim and prefigure the Kingdom of God." 40 By beginning with a First Temple understanding and continuing to build from there - on that firm foundation the Church can collectively grow into "the initial phase of the building of the final temple that will appear at the end of the age." ${ }^{41}$ A creative coalescence is seen here as the Church morphs into what it was called to be all along, unified in Christ-like charity and service under the loving direction of the Savior. Truly, this is a phenomenon that is deeply mystical in nature, just as the Temple itself contained vast mysteries known fully only among the presence of the Divine Council.

6.1.2 Renewing Temple Vision

The goal then becomes to develop a theology of the Temple that is both grounded in biblical cosmology and is mystically transformative in nature. Especially within our increasing technological age, where 'reality' is growing more and more intangible (and virtual) by the minute, humanity is looking beyond the physical realm for connections, whether through psychic or supernatural phenomenon. Temple vision offers these deeper mystical connections, and does so in a way that is uniquely reflective of a biblical worldview and consistent with the earthly mission of Jesus Christ. Within the confines of the Temple, one can seek answers and experience a sense of timelessness unparalleled to the outside world. One can truly commune with the unseen world and become endowed with power from on high. The hidden things of God can be revealed to humanity, and humanity can commune with God. Within the confines of the Temple, the mystical unity for which Christ prayed becomes a very real possibility. Additionally, the Temple can bridge that essential gap between Jew and Gentile alike because it is grounded in the sacred scriptures and traditions both hold dear. The gathering of Israel becomes a very real possibility when considered in light of Temple discourse.

\section{In the Absence of a Temple}

But how is this to be understood in the absence of a physical Temple? Perhaps the Church of Jesus Christ of Latter-day Saints, popularly known as Mormons, offers the key. Many would not think to look in this direction because the beliefs of the church stand in contrast to traditional Christian theology. That said, one thing is for sure: the towering presence of the Temple. At present, 217 Latter-day Saint Temples exist worldwide, 166 Temples have been dedicated, sixteen are presently under construction, and thirty-five new Temples have recently been announced, as of Fall 2019 General Conference. ${ }^{42}$ The Temples, with their saving ordinances and corresponding three degrees of glory - with the Celestial Room as the Holy of Holies - replicate in a very real and tangible way the original Temple design of King Solomon. For Latter-day Saints, the Temple is the place where celestial glory meets temporal reality. The goal remains to gather Israel, as Latter-day Saints view 
themselves as an extension of the tribe of Ephraim - the House of Israel of mixed lineage - which was scattered to the northern countries after being conquered by the Assyrians in 722 BCE. While there could be some dispute over logistics concerning the whereabouts of the Lost Tribes, the presence of Latter-day Temples spanning the entire globe stands as a testament to its enduring quality, considering it all began with the vision of a young Joseph Smith back in 1823 in a sacred grove among the oak trees (see Isaiah 61:3) - an enduring symbol of this hidden Sacred Feminine presence. It should be kept in mind that the northern kingdom of Israel had its own fully functioning Temple on Mt. Gezirim back in biblical times, with plentiful sacred groves dotting the landscape.

\subsection{The Gathering of Israel}

The gathering of Israel becomes more than just a remote dream when considered in light of recent plans to rebuild the Third Temple. This remains an issue of controversy among Jews and Christians alike, as plans to rebuild and rededicate have been in progress since 1987 under the direction of the Temple Institute in Jerusalem. ${ }^{43}$ In September 2014, an official report issued by the Temple Institute states that $\$ 71,000$ had been raised in support of the efforts. ${ }^{44}$ The difficulty remains that not many secular or religious Jews alike offer their support, due partly to conflict with Muslims regarding rightful ownership of the Temple Mount where the historic Dome of the Rock is located. Additionally, there are efforts underway to find the original location of King Solomon's Temple, as it is believed that the Temple Mount may not have been the original location. Nevertheless, the Temple Institute has made it their goal and mission to not only support rebuilding efforts, but to educate the public on the importance of rebuilding the Third Temple, coupled with the hope that Moshiac (Messiah) will return. Similarly, many evangelical Christians support the rebuilding efforts because they believe it will inaugurate the Second Coming.

Despite the ongoing controversy, efforts have been made towards realizing this goal of rebuilding the Temple. DNA testing is being conducted to determine those of Levitical descent and provides that genetic confirmation necessary in selecting those who will preside in the new Temple. Consistent with these plans, "a field school was built in Mizpe Yericho to prepare Kohanim (priests) and Levites for service in the Third Temple" 45 in 2009, where hands-on training is provided by way of life-sized artifact replicas. In September 2018, a red heifer was born and certified ritually pure for sacrifice by a rabbinic board in accordance with the nineteenth chapter of Numbers. The efforts are sponsored by the Temple Institute through the Raise a Red Heifer Initiative, which includes genetic manipulation through embryo implants. ${ }^{46}$ This is important in reinstated ritual sacrifice as it was once practiced in the Temple and is not contrary to the Hebrew Scriptures since Jacob himself practiced an ancient form of genetic modification with his uncle Laban's goats in Genesis 30:25-43. Additionally, in late 2018, President Donald Trump moved the U.S. embassy from Tel Aviv to Jerusalem; for this reason, he is viewed as a modern-day Cyrus figure. It would appear from the above 'signs' that the time is close for the inauguration of the Third Temple in Jerusalem. Despite criticism, the stage is being set and world conditions are increasingly changing in favor of this effort.

7.1.1 The Third Temple

The Third Temple can become the catalyst whereby which Judah is gathered in time before the Messiah's return. Once again, the answer lies in mutual cooperation in a spirit of visible unity - not only among Christians, but among both Christians and Jews. Latter-day Saints with their fully-functioning Temples already fully grasp this concept. The 1972 Ensign declares, "The future of the Holy Land is closely allied with the future of the House of Israel, more specifically with the future of the descendents of Judah."47 This is seen in direct fulfillment of Ezekiel 37:15-17, which declares the 'sticks' of Ephraim and Judah will someday be joined together as one. Working collectively in a true spirit of 'Holiness unto the LORD,' - as inscribed on Latter-day Temples - the coming of the Messiah can be brought into fruition as Israel and Judah, each through their respective Temples, become a light unto all other nations. There remains much to be said concerning the rebuilding of the Third Temple in Jerusalem in support of these efforts, and in the search for theological convergence.

Much could be gained from a careful study of Latter-day Temples within ecumenical circles, since many mainstream Christians lack knowledge of the intricacies of this belief system, with its unique historical and cosmological perspective. A clear Temple vision is evident in Latter-day discourse that maintains consistency with a biblical worldview. While there remains confusion as to from where Latter-day Saints derive their restorationist understanding of their own continuity with Church tradition - or lack thereof - Margret Barker points to the possibility of a hidden Temple tradition, or argument from silence, within early Christianity. Barker points to the Patristic writings as evidence to support her theory. Quoting from Clement of Alexandria's lost Hypotyposes, Eusebius writes, "To James the Just, and John and Peter, the Lord after His resurrection imparted knowledge. These imparted it to the rest of the apostles, and the rest of the apostles to the Seventy, of whom Barnabus was one." ${ }^{48}$ Regarding this, Barker adds in her own translation of Eusebius that the Savior imparted "the higher knowledge" 49 to his disciples, which remained unwritten for those within Jesus' inner circle. Given the mystical nature of Jesus' teachings regarding the Spirit Realm and coming Kingdom of God, it would not be surprising if these secret traditions were carry-overs from the ancient Temple tradition. 


\section{Enlarging the Vision}

But even in the absence of a physical Temple, or even in the absence of an in-depth knowledge of lost Temple traditions, hope remains. Gregory K. Beale provides an answer to this dilemma that would resonate with most traditional Christians, including evangelicals. Beale views the Church as the New Israel, and therefore as a fullyfunctioning Temple in its own right, as the visible Body of Christ on earth in anticipation of the future Cosmic Temple. Citing Revelation 3:12, Beale describes the collective Church "becoming indentified eternally with the 'temple' (naos) by being made a permanent 'pillar' (stylos) in it." ${ }^{, 50}$ This is in the absence of a physical Temple, as reiterated in Revelation 21-22 concerning the coming future celestial Temple. As Beale understands, the perfected Church will become the Holy City and dwelling place of God. No physical temple construct is needed in the Celestial Temple because it remains a place of pure light, love, and perfect visible unity among God's people. The light of the Shekinah glory will be forever in their midst.

There is something to be noted about the incarnational aspects of Beale's thesis. Going along with the 'body as a Temple' concept (I Corinthians 6:19-20), each member has an important role to play in realizing Israel's collective mission on earth. This is not only, now but throughout the ages. Whether it is through ministry, enduring persecution, personal sacrifice, or just daily faithful living, all professing Christians can contribute to "building up the temple on the foundation of Christ," ${ }_{1}$ as well as extending the boundaries of influence throughout the world in accordance with Jesus' Great Commission, as is consistent with Israel's worldwide mission. In this sense, the Church becomes an extension of Israel through faith and practice. May the Church continue to grow into the covenant community and royal priesthood is it called to be so that God's presence is felt throughout the entire earth until the day Christ returns. This is consistent with Jesus' mystical prayer for visible unity in John 17:21. This is Temple vision as seen from beyond the veil.

\section{Recommendations for Further Research}

The modern Ecumenical Movement still has a long way to go before visible unity is fully realized. These goals can be obtained through future research into the role of First Temple Judaism nostalgia as understood in the aftermath of King Josiah's reforms, and later as pertaining to Jesus' earthly ministry. Further research could be conducted into the polytheistic origins of the Hebrew faith, as to recover the lost Sacred Feminine presence within the Temple, and in fostering a certain level of intellectual honesty within Christian theological discourse. Additionally, Latter-day Saint voices can add perspective to the discussion, as pertaining, not only to Temple discourse, but to a more complete, or fuller understanding of theological convergence.

\section{References}

Bailey, Alice. Education in the New Age. The Books of Alice Bailey. Lucis Trust, 1954. https://www.lucistrust.org/online books/education in the new age obooks.

Barker, Margaret. Temple Theology: An Introduction. London: Society for Promoting Biblical Knowledge, 2004.

- The Great Angel: A Study of Israel's Second God. First Edition edition. Louisville, Ky: Westminster John Knox Press, 1992.

. The Mother of the Lord: The Lady in the Temple. London: Bloomsbury, 2012.

"The Secret Tradition." Journal of Higher Criticism 2, no. 1 (1995): 37-67.

Beale, G.K. The Temple and the Church's Mission: A Biblical Theology of the Dwelling Place of God. Downers Grove: InterVarsity Press (IVP) Academic, 2004.

Berkowitz, Adam Eliyahu. "Red Heifer Birth, Paves Way for Renewed Temple Service." Breaking Israel News. Last modified September 5, 2018. https://www.breakingisraelnews.com/113476/temple-institute-certifiesred-heifer/.

Cullinane, Peter J. "Transforming the Church Isn't Finished Yet." The Australasian Catholic Record 95, no. 1 (January 2018): 3-9.

Domeris, William. "The 'Enigma of Jesus' Temple Intervention: Four Essential Keys." HTS Teologiese Studies/Theological Studies 71, no. 1 (July 29, 2015): 1-8.

Dvorin, Tova. "Crowdfunding Campaign for the Third Temple Close to Goal." The Temple Institute. Last modified September 17, 2014. https://www.templeinstitute.org/archive/17-09-14.htm.

Edelman, Diana V., ed. The Triumph of Elohim: From Yahwisms to Judaisms. Contributions to Biblical Exegesis \& Theology 13. Peeters Publishers, 1995.

Eusebius. "Ecclesiastical History VII." AnteNicene Fathers. http://www.newadvent.org/fathers/250107.htm.

Gignilliat, Mark. "Oaks of Righteousness for His Glory: Horticulture and Renewal in Isaiah 61,1-4." Zeitscrift fur die Alttestamentlidhe Wissenschaft 123, no. 3 (2011): 391-405.

de Gruchy, John W. "Recovering Ecumenical Vision and a Commitment in a Post-Ecumenical Era." Journal of Theology for Southern Africa 102 (November 1998): 1-12.

Heiser, Michael S. Reversing Hermon: Enoch, the Watchers, and the Forgotten Mission of Jesus Christ. Defender Publishing, 2017. 
Ludlow, Daniel H. "The Future of the Holy Land.” Church of Jesus Christ of Latter-day Saints. Ensign. Last modified May 1972. https:/www.churchofjesuschrist.org/study/ensign/1972/05/the-future-of-the-holyland?lang=eng.

Malina, Bruce J. On the Genre and Message of Revelation: Star Visions and Sky Journeys. Peabody, Massachusetts: Hendrickson Publishers, 1995.

Miller, Robert D. "Tracking the Dragon Across the Ancient Near East.” Archiv Orientalni 82, no. 2 (2014): 225245.

Patai, Raphael. "The God Yahweh-Elohim.” American Antropologist 75, no. 4 (1973).

Plater, Ormonde. "Ecumenical Documents on Ministry (1873-1999)." Anglican Theological Review 83, no. 3 (Summer 2001): 613-618.

Steiner, Richard C. "On the Rise and Fall of Canaanite Religion at Baalbek: A Tale of Five Toponyms." Journal of Biblical Literature 128, no. 3 (2009): 507-525.

Teubal, Savina J. Sarah the Priestess: The First Matriarch of Genesis. Athens, Ohio: Swallow Press, 1984.

Thomas, Ryan. "The God Gad." Journal of the American Oriental Society 139, no. 2 (2019): 307-316.

"Baptism, Eucharist and Ministry: WCC Commission on Faith and Order, Lima, 1982." In The Ecumenical Movement: An Anthology of Key Texts and Voices, 176-200. Geneva, Switzerland/Grand Rapids, Michigan: WCC Publications/Eerdman's, 1997.

"Israel's Priests Prepare for the Third Temple." The Messianic Prophecy Bible Project. Last modified 2019. https://free.messianicbible.com/feature/israels-priests-prepare-third-temple/.

“Temple Statistics." Church of Jesus Christ Temples.Org. Last modified 2019. https://churchofjesuschristtemples.org/.

"The Unity of the Church as Koinonia: Gift and Calling." In The Ecumenical Movement: An Anthology of Key Texts and Voices, 124-125. Geneva, Switzerland/Grand Rapids, Michigan: WCC Publications/Eerdman's, 1997.

"Update on the Building of the Third Temple." Jewish Voice Ministries International. Last modified 2019. https://www.jewishvoice.org/read/article/update-building-third-temple.

\section{Notes}

1 "The Unity of the Church as Koinonia: Gift and Calling," in The Ecumenical Movement: An Anthology of Key Texts and Voices (Geneva, Switzerland/Grand Rapids, Michigan: WCC Publications/Eerdman's, 1997), 125.

2 "Baptism, Eucharist and Ministry: WCC Commission on Faith and Order, Lima, 1982," in The Ecumenical Movement: An Anthology of Key Texts and Voices (Geneva, Switzerland/Grand Rapids, Michigan: WCC Publications/Eerdman's, 1997), 195.

${ }^{3}$ John W. de Gruchy, "Recovering Ecumenical Vision and a Commitment in a Post-Ecumenical Era," Journal of Theology for Southern Africa 102 (November 1998): 2.

${ }^{4}$ G.K. Beale, The Temple and the Church's Mission: A Biblical Theology of the Dwelling Place of God (Downers Grove: InterVarsity Press (IVP) Academic, 2004), 134.

${ }^{5}$ Margaret Barker, Temple Theology: An Introduction (London: Society for Promoting Biblical Knowledge, 2004), 42 .

${ }^{6}$ Ibid., 25.

${ }^{7}$ Ibid., 58 .

${ }^{8}$ Ibid., 9.

${ }^{9}$ Ibid., 77.

${ }^{10}$ Mark Gignilliat, "Oaks of Righteousness for His Glory: Horticulture and Renewal in Isaiah 61,1-4," Zeitscrift fur die Alttestamentlidhe Wissenschaft 123, no. 3 (2011): 394.

${ }^{11}$ Savina J. Teubal, Sarah the Priestess: The First Matriarch of Genesis (Athens, Ohio: Swallow Press, 1984$), 88$.

12 Diana V. Edelman, ed., The Triumph of Elohim: From Yahwisms to Judaisms, Contributions to Biblical Exegesis \& Theology 13 (Peeters Publishers, 1995), 34.

${ }^{13}$ Margaret Barker, The Great Angel: A Study of Israel's Second God, First Edition edition. (Louisville, Ky: Westminster John Knox Press, 1992), 21.

${ }^{14} \mathrm{El}$ was also a generic name for any given deity, but could be a personal name. Elyon implies the distinction

"Most High."

${ }^{15}$ Barker, The Great Angel, 4.

${ }^{16}$ Raphael Patai, "The God Yahweh-Elohim,” American Antropologist 75, no. 4 (1973): 1183.

${ }^{17}$ Robert D. Miller, "Tracking the Dragon Across the Ancient Near East," Archiv Orientalni 82, no. 2 (2014): 225.

${ }^{18}$ Ibid., 237.

${ }^{19}$ Ryan Thomas, “The God Gad,” Journal of the American Oriental Society 139, no. 2 (2019): 310. 
${ }^{20}$ Bruce J. Malina, On the Genre and Message of Revelation: Star Visions and Sky Journeys (Peabody, Massachusetts: Hendrickson Publishers, 1995), 48.

${ }^{21}$ Margaret Barker, The Mother of the Lord: The Lady in the Temple (London: Bloomsbury, 2012), 45.

${ }^{22}$ Michael S. Heiser, Reversing Hermon: Enoch, the Watchers, and the Forgotten Mission of Jesus Christ (Defender Publishing, 2017), 103.

${ }^{23}$ Ibid., 95. Italics by author for added emphasis.

${ }^{24}$ Ibid.

${ }^{25}$ Ibid.

${ }^{26}$ Richard C. Steiner, "On the Rise and Fall of Canaanite Religion at Baalbek: A Tale of Five Toponyms," Journal of Biblical Literature 128, no. 3 (2009): 511-512. See also R. Thomas, "The God Gad," JAOS, 311.

27 "Baptism, Eucharist and Ministry: WCC Commission on Faith and Order, Lima, 1982," 194.

${ }^{28}$ Ormonde Plater, "Ecumenical Documents on Ministry (1873-1999)," Anglican Theological Review 83, no. 3 (Summer 2001): 617.

${ }^{29}$ Peter J. Cullinane, “Transforming the Church Isn't Finished Yet,” The Australasian Catholic Record 95, no. 1 (January 2018): 4.

30 Alice Bailey, Education in the New Age, The Books of Alice Bailey (Lucis Trust, 1954), 150, https://www.lucistrust.org/online_books/education_in_the_new_age_obooks.

${ }^{31}$ Heiser, Reversing Hermon: Enoch, the Watchers, and the Forgotten Mission of Jesus Christ, 96.

${ }^{32}$ Ibid.

${ }^{33}$ Beale, The Temple and the Church's Mission: A Biblical Theology of the Dwelling Place of God, 85.

${ }^{34}$ Ibid.

35 Ibid., 99.

${ }^{36}$ Ibid., 97.

${ }^{37}$ Ibid., 263.

${ }^{38}$ Barker, The Mother of the Lord: The Lady in the Temple, 49.

${ }^{39}$ William Domeris, “The 'Enigma of Jesus' Temple Intervention: Four Essential Keys," HTS Teologiese Studies/Theological Studies 71, no. 1 (July 29, 2015): 3.

40 "Baptism, Eucharist and Ministry: WCC Commission on Faith and Order, Lima, 1982," 190.

${ }^{41}$ Beale, The Temple and the Church's Mission: A Biblical Theology of the Dwelling Place of God, 262.

42 "Temple Statistics," Church of Jesus Christ Temples.Org, last modified 2019, https://churchofjesuschristtemples.org/.

43 "Update on the Building of the Third Temple," Jewish Voice Ministries International, last modified 2019, https://www.jewishvoice.org/read/article/update-building-third-temple.

${ }^{44}$ Tova Dvorin, "Crowdfunding Campaign for the Third Temple Close to Goal," The Temple Institute, last modified September 17, 2014, https://www.templeinstitute.org/archive/17-09-14.htm.

45 "Israel's Priests Prepare for the Third Temple," The Messianic Prophecy Bible Project, last modified 2019, https://free.messianicbible.com/feature/israels-priests-prepare-third-temple/.

${ }^{46}$ Adam Eliyahu Berkowitz, "Red Heifer Birth, Paves Way for Renewed Temple Service," Breaking Israel News, last modified September 5, 2018, https:/www.breakingisraelnews.com/113476/temple-institute-certifies-redheifer/.

${ }^{47}$ Daniel H. Ludlow, "The Future of the Holy Land," Church of Jesus Christ of Latter-day Saints, Ensign, last modified May 1972, https:/www.churchofjesuschrist.org/study/ensign/1972/05/the-future-of-the-holyland?lang=eng.

${ }^{48}$ Eusebius, "Ecclesiastical History VII," AnteNicene Fathers, http://www.newadvent.org/fathers/250107.htm.

${ }^{49}$ Margaret Barker, "The Secret Tradition,” Journal of Higher Criticism 2, no. 1 (1995): 37-67.

${ }^{50}$ Beale, The Temple and the Church's Mission: A Biblical Theology of the Dwelling Place of God, 328.

${ }^{51}$ Ibid., 400.

Dr. Michelle G. Wiener earned her PhD in Comparative Christian Theology through Euclid University in November, 2019. She is a graduate of Lexington Theological Seminary (M.A., 2004) in Lexington, Kentucky, and the Ecumenical Institute Bossey of the World Council of Churches in Geneva, Switzerland, where she received a Master of Ecumenical Studies through the University of Geneva in 2005. She is currently taking spirituality courses with the Lorian Association. Dr. Wiener is a convert to the Church of Jesus Christ of Latterday Saints and made sacred covenants in the Columbia, South Carolina Temple in December, 2018. Her PhD dissertation is entitled "Thinking Outside the Cube: Temple Theology as an Emerging and Synthetic Worldview Paradigm for Ecumenical and Interfaith Studies." She is an Instructor of Religion and also teaches Developmental English at Rowan-Cabarrus Community College. 